\title{
GEOLOGICAL MAGAZINE
}

\section{CONTENTS}

PAGB

FREUND, RAPHAEL. A Model of the Structural Development of Israel and Adjacent Areas Since Upper Cretaceous Times

HILL, D., and R. K. JULL. Note on Campophyllum flexuosum (Goldfuss)

HOLLAND, C. H. The Siluro-Devonian Boundary.

HAWKINS, T. R. W. A Note on Rhythmic Layering in Hornblenderich Picrite and Dolerite Intrusions, near Rhiw, Caernarvonshire . 222

LIVINGSTONE, A. An Olivine-bearing Sagvandite from Berneray, Outer Hebrides

WYLLIE, PETER J. A Modification of the Geosyncline and Tectogene Hypothesis

BAYLY, M. B. A Correlation Between Cleavage-fan Angle and Bed Thickness

FURNESS, R. R. The Petrography and Provenance of the Coniston Grits East of the Lune Valley, Westmorland. . .

HOWARTH, M. K., and P. F. RAWSON. The Liassic Succession in a Clay Pit at Kirton in Lindsey, North Lincolnshire .

AUDLEY-CHARLES, M. G. A Miocene Gravity Slide Deposit from Eastern Timor .

CORRESPONDENCE, pp. 277-9

REVIEWS, pp. 279-283

PUBLICATIONS RECEIVED, p. 284 


\section{GEOLOGICAL MAGAZINE \\ founded in 1864 \\ incorporating \\ THE GEOLOGIST \\ (founded 1858) \\ Edited by \\ O. M. B. BULMAN, S. R. NOGKOLDS, and \\ W. B. HARLAND \\ assisted by \\ Professor W. G. Fearnsides Professor O. T. Jones \\ Professor leonard Hawkes Sir William Pugh \\ Professor C. E. THLLeY}

The Editors are directed to make it known to the public that the authors alone are responsible for the facts and opinions contained in their respective papers and for the correctness of their references.

\section{Instructions to Contributors.}

Articles submitted for publication in the Geological Magazine should be addressed to the Editors at the Sedgwick Museum, Cambridge, not to the Publishers.

Manuscripts should be typewritten, double-spaced, and preferably with a wide margin, and should be carefully revised; they should be as concise as possible and should not exceed 10,000 words. In the case of a long article allowance must be made for text-figures at the rate of approximately twenty words per sq. in. MS. must be accompanied by a short abstract, $50-100$ words. References should not be given in footnotes, but arranged in alphabetic order of author's names at the end of the article; the author's name should be followed by date of publication, and the title of each paper should be given in addition to volume and page numbers of the Journal. The name of the Journal should be abbreviated according to the form in the World List of Scientific Periodicals (3rd Ed., London, 1952). Example:-LAPwORTH, C. 1878. The Moffat Series. Quart. J. geol. Soc. Lond., 34, 240-343.

References should be cited in the text by author's name and date with page reference if necessary, in brackets:- (Lapworth, 1878, p. 339).

Illustrations should be so drawn as to allow reduction to a maximum size of $6 \frac{3}{4} \times 3 \frac{3}{4}$ inches (the type-area of the Magazine) and originals must not exceed $40 \times 22$ inches. Map lettering should be such as to be clearly legible after reduction (equivalent to 5 -point as a minimum on reduction).

Authors will receive 25 reprints free of cost.

Published Bi-monthly U.K. $60 /$ - Overseas $\$ 11$ U.S. per annum (single numbers, 16/6)

Subscriptions for 1965 , inquiries relating to back stock, advertising, etc., should be sent to Stephen Austin \& Sons, Ltd., Caxton Hill, Ware Road, Hertford, Herts.

Complete unbound volumes prior to 1965 (where available), £5. 